\title{
ANALISIS WEWENANG NOTARIS DALAM PEMBUATAN AKTA PERJANJIAN PENGIKATAN JUAL BELI HAK MILIK ATAS TANAH DI KOTA MAKASSAR
}

\author{
Analysis of the Authority of Notary in Making the Deed of Contract Sale and Purchase of Land in \\ Makassar City
}

\author{
Sry Wahyuni ${ }^{1}$, Baso Madiong ${ }^{1}$, Zulkifli Makkawaru ${ }^{1}$ \\ ${ }^{1}$ Magister Ilmu Hukum Program Pascasarjana, Universitas Bosowa \\ ${ }^{2}$ Program Studi Ilmu Hukum, Program Pascasarjana, Universitas Bosowa \\ Email: unhymjcarlos@gmail.com
}

Diterima: 07 Januari 2021

Dipublikasikan: 02 Juni 0221

\begin{abstract}
ABSTRAK
Penelitian ini ditujukan untuk menganalisis kewenangan notaris dalam membuat akta Perjanjian Pengikatan Jual Beli dan menganalisis perlindungan hukum terhadap para pihak Atas akta Notaris dalam perjanjian pengikatan jual beli hak milik atas tanah di Kota Makassar. Penelitian ini adalah penelitan hukum empiris yang menggunakan pendekatan perundang-undangan dan konseptual. Penelitian ini menjawab masalah yakni wewenang Notaris dalam pembuatan Akta Perjanjian Pengikatan Jual Beli tanah yang ada di Kota Makassar merupakan kewenangan yang melekat pada Notaris untuk membuat akta mengenai semua perbuatan, perjanjian dan penetapan yang diharuskan oleh peraturan Perundang-undangan dan/atau yang dikehendaki oleh yang berkepentingan untuk dinyatakan dalam Akta Autentik termasuk perjanjian pengikatan jual beli dan Perjanjian Pengikatan Jual Beli dapat digunakan sebagai bentuk perlindungan hukum bagi para pihak yang termuat dalam perjanjian tersebut dan dapat menjadi salah satu alat bukti jika suatu saat terjadi perselisihan antara para pihak karena akta Perjanjian Pengikatan Jual Beli diakui sebagai alat bukti yang sah dan akurat bagi para pihak yang melakukan transaksi perjanjian jual beli sebagaimana disebutkan dalam Undang-Undang bahwa akta autentik digunakan sebagai alat bukti dengan pembuktian sempurna dihadapan hukum.
\end{abstract}

Kata Kunci: Otoritas Notaris; Akta otentik; PPAT;

\begin{abstract}
This research addressed at analyzing the notary authority in making the sale and purchase agreement deed and analyzing legal protection of the parties on the notary deed in the sale and purchase agreement of land ownership in Makassar City. This paper used a legal empiric research by applying legislations, and conceptual approach. This study revealed the answer that the authority of the Notary in making the Deed of the Agreement of Sale and Purchase of land in Makassar City is the authority attached to the Notary to make deeds regarding all actions, agreements and stipulations required by the laws and regulations and / or those interested in being stated in the Deed. Authentic, including the sale and purchase agreement and the Sale and Purchase Agreement can be used as a form of legal protection for the parties contained in the agreement and can be used as evidence if a dispute occurs between the parties because the deed of the Sale and Purchase Agreement is recognized as evidence which is valid and accurate for parties conducting sale and purchase agreement transactions as stated in the Law that authentic deeds are used as evidence with perfect proof before the law..
\end{abstract}

Keywords: Notary Authority; Authentic deed; PPAT;

\section{PENDAHULUAN}

Dalam konsep hukum administrasi negara, setiap tindakan atau perbuatan pemerintah harus berdasarkan hukum, karena dalam negara hukum terdapat prinsip wetmatigheid van bestuur atau asas legalitas. Hal ini pun berlaku bagi Notaris. Dalam menjalankan profesinya, Notaris berpedoman pada Undang-Undang Jabatan Notaris dan peraturan pelaksananya. Inilah yang menjadi pedoman serta pegangan bagi setiap orang yang berprofesi sebagai Notaris, di mana dalam menjalankan tugas dan kewajibannya tidak boleh bertentangan dengan ketentuan peraturan perundang-undangan. Ketentuan yang tidak hanya mengatur mengenai bagaimana seharusnya Notaris menjalankan tugas jabatannya, tetapi juga mengatur prilaku Notaris mengenai dan bagaimana seharusnya Notaris bersikap dan bertindak, bukan hanya terhadap klien atau pihak yang memakai jasanya tetapi juga bagaimana bersikap terhadap sesama rekan profesi atau Notaris lainnya serta masyarakat pada umumnya.

Notaris dan PPAT menjalankan fungsi negara, maka kehadiran negara diperlukan untuk menjaga agar Notaris dan PPAT tetap berada dalam koridor yang telah ditetapkan. Dalam hal ini, Notaris berada di bawah pembinaan dan pengawasan pemerintah, yang dilakukan oleh Kementerian Hukum dan Hak Asasi Manusia dan PPAT oleh Kementerian ATR-BPN.

Setiap orang memiliki kebutuhan dasar seperti tempat tinggal, kebutuhan tersebut akan mendorong terjadinyaf transaksi jual beli rumah atau tanah. Para pihak yang hendak melakukan proses jual beli tanah dengan transaksi yang besar. Memerlukan perlindungan 
hukum yang baik, Perlindungan hukum tersebut telah dapat diatur oleh pemerintah dan beberapa telah menjadi kewenangan Notaris dan Pejabat Pembuat Akta Tanah (PPAT) selaku pejabat Negara.

Jual beli merupakan suatu bentuk perjanjian yang melahirkan kewajiban atau perikatan untuk memberikan sesuatu yang dalam hal ini terwujud dalam bentuk penyerahan kebendaan yang dijual oleh penjual dan penyerahan uang oleh pembeli kepada penjual. Jual beli adalah perjanjian timbal balik dalam pihak yang satu (penjual) berjanji untuk menyerhakan hmilik atas suatu barang sedangkan pihak lainnya (pembeli) berjanji untuk membayar harga barang yang terdiri atas sejumlah uang sebagai imbalan dari perolehan hak milik tersebut.

Notaris dan PPAT diberi wewenang oleh Negara untuk membuat akta autentik mengenai semua perbuatan, perjanjian dan penetapan yang diharuskan oleh peraturan Perundang-undangan dan/atau yang dikehendaki oleh yang berkepentingan untuk dinyatakan dalam Akta Autentik menjamin kepastian tanggal Pembuatan Akta, menyimpan Akta, memberikan grosee, selain dan kutipan Akta semuanya itu sepanjang pembuatan Akta itu tidak juga ditugaskan atau dikecualikan kepada pejabat lain . Akta-akta yang dibuat oleh Notaris dan PPAT adalah akta yang autentik dimana mengikat para pihak yang tercantum di dalamnya untuk melindungi masing-masing pihak dari kejadian-kejadian yang dapat merugikan salah satu pihak.

Pembuatan dokumen-dokumen penting ini adalah kegiatan yang memerlukan ilmu dan kecermatan yang tinggi sehingga akta yang dibuat oleh Pejabat Negara tersebut dapat membantu para pihak dalam bertransaksi atau melakukan kegiatan tertentu. Sebab apabila pembuatan akta tidak dengan cermat dan sesuai dengan peraturan Perundang-undangan serta kode etik dapat menimbulkan permasalahan di kemudian hari. Terkait hal tersebut Negara juga sudah mempersiapkan pengawasan terhadap Notaris dan PPAT secara internal dan eksternal.Pengawasan internal terhadap Notaris dilakukan oleh Ikatan Notaris Indonesia. Kemudian untuk pengawasan eksternal dilakukan oleh Kementerian Hukum dan HAM melalui Majelis Pengawasa Notaris dan Majelis Kehormatan Notaris. Sedangkan PPAT berada dibawah pembinaan dan pengawasna Kementerian ATRBPN.

Notaris berwenang membuat akta autentik menganai semua perbuatan, perjanjian dan ketetapan yang diharuskan oleh Peraturan Perundang-undangan dan/atau yang dikehendaki oleh yang berkepentingan untuk untuk dinyatakan dalam akta otentik. Menjamin kepastian tanggal pembuatan akta, menyimpan akta, memberikan grosee, salinan dan kutipan akta, semuanya itu sepanjang pembuatan akta-akta itu tidak juga ditugaskan atau dikecualikan kepada pejabat lain atau orang lain yang ditetapkan oleh Undang-Undang.

Banyaknya ketentuan mengenai perbuatan-perbuatan Notaris dalam melaksanakan kewenangnya sebagaimana mengacu pada salah satu asas pemerintahan yang baik,
Notaris dalam menjalankan tugas jabatannya wajib berpedoman secara normative kepada aturan hukum yang berkaitan dengan segala tindakan yang akan diambil untuk kemudian dituangkan dalam akta. Bertindak berdasarkan aturan hukum yang berlaku akan memberikan kepastian kepada para pihak, bahwa akta yang dibuat di hadapan atau oleh Notaris telah sesuai dengan aturan hukum yang berlaku sehingga jika terjadi permasalahan Akta Notaris dapat dijadikan pedoman para pihak.

Notaris dalam menjalankan kewenangannya harus memperhatikan kewajibannya sebagaimana diatur dalam Undang-Undang Jabatan Notaris dan Kode Etik Notaris serta peraturan Perundang-undangan.Disamping itu Notaris juga harus memperharikan asas kecermatan dalam membuat akta. Notaris dalam mengambil suatu tindakan harus dipersiapkan dan didasarkan pada aturan hukum yang berlaku. Meneliti semua bukti yang diperlihatkan kepada Notaris dan mendengarkan keterangan atau pernyataan para pihak wajib dilakukan sebagai bahan dasar untuk dituangkan dalam akta. Hal ini diperlukan untuk meminimalisasi adanya kesalahan yang dapat menimbulkan sengketa dikemudian hari.

\section{METODE}

Jenis penelitian dalam penelitian ini adalah yuridis empiris yang dengan kata lain adalah jenis penelitian hukum sosiologis. Teknik pengumpulan data dalam penelitian ini adalah dengan mempergunakan cara, yakni:

1. Wawancara kepada Notaris.

2. Kuisioner.

Peneliti membuat pertanyaan secara tertulis kepada responden yang dipilih sebanyak 50 orang.

\section{HASIL DAN PEMBAHASAN}

Wewenang Notaris dalam Pembuatan Akta Pengikatan Jual Beli Hak Milikl Atas Tanah di Kota Makassar

Wewenang Notaris dalam pembuatan Akta Perjanjian Pengikatan Jual Beli Hak Milik Atas Tanah yang dilakukan oleh Notaris yaitu bahwa Notaris berwenang untuk membuat akta pengikatan jual beli dengan ketentuan bahwa semua persyaratan dalam pembuatan akta terpenuhi dengan lengkap baik dari aspek prosedur pembuatan maupun substansi akta sesuai dengan kewenangan yang dimiliki oleh notaris berdasarkan peraturan perundang-undangan yang berlaku.

Hasil wawancara Dra Siti Hasnati, SH, Selaku Notaris dan PPAT menyatakan:

"Akta Perjanjian Pengikatan Jual Beli Hak Milik Atas Tanah merupakan tanda bukti pengikatan perjanjian jual beli tanah antara para pihak, guna memberikan perlindungan hukum dan menjaga kepentingan para pihak yang akan melakukan transaksi jual beli tanah atau tanah dan bangunan yang belum memenuhi syarat untuk dibuatkannya Akta Jual Beli maka dibuatkanlah Perjanjian pengikatan untuk Jual Beli sesuai dengan kesepakatan yang tertuang dalam perjanjian. Setelah 
seluruh syarat formil dan materil terpenuhi, barulah PPAT membuat perpindahan hak kepemilikan tanah dengan membuat Akta Jual Beli yang akan dijadikan dasar untuk mengajukan pengalihan kepemilikan tanah kepada instansi yang berwenang, yakni Badan Pertanahan Nasional/Kementerian ATR BPN .

Notaris berwenang membuat akta autentik sepanjang pembuatan akta-akta itu tidak juga ditugaskan atau dikecualikan kepada pejabat lain di antaranya PPAT, Pejabat Lelang atau Kantor Catatan Sipil dan Kewenangan lainnya selain membuat akta autentik. Sedangkan PPAT berwenang membuat akta terbatas (limitatife) pada delapan akta sebagaimana yang telah disebut diatas dan kewenangan PPAT yang tidak meranggap sebagai Notaris diberi wewenang untuk dapat melakukan pengesahan kecocokan fotocopi. Kesamaan Antara Notaris dan PPAT adalah bahwa akta-akta yang dibuat mereka adalah akta autentik.

Sesuai dengan ketentuan Pasal 7 Peraturan Pemerintah Nomor 24 Tahun 1997 Tentang Pendaftaran Tanah maka diterbitkan Peraturan Jabatan Pejabat Pembuat Akta Tanah. Kemudian Pasal 1 ayat (1) PP Nomor 37 Tahun 1997 tersebut menyebutkan bahwa Pejabat Pembuatan Akta Tanah (PPAT) adalah pejabat umum yang diberi kewenangan untuk membuat akta-kata otentik mengenai perbuatan hukum tertentu mengenai hak atas tanah atau hak milik satuan rumah susun.

Mengingat tugas dari pemangku jabatan PPAT tersebut, tentunya dalam penyelenggaraan jabatan PPAT itu tidak menutup kemungkinan terjadinya kekosongan PPAT di suatu kabupaten/kota sebagai akibat luasnya wilayah teritorial Negara Kesatuan Republik Indonesia (NKRI). Untuk menyikapi kondisi tersebut, para perumus ketentuan mengenai PPAT mengadakan dan/atau menunjuk pejabat lainnya untuk mengemban jabatan PPAT. Pejabat lain yang diberikan kewenangan untuk mengemban jabatan PPAT adalah Camat atau Kepala Desa, yang setelah mengangkat sumpah jabatan akan didaulat sebagai PPAT Sementara sebagaimana dimaksud dalam Pasal 5 Ayat (3) huruf a Peraturan Pemerintah Nomor 37 Tahun 1998 Tentang Pejabat Pembuat Akta Tanah sebagaimana telah diubah dengan PP Nompr 24 Tahun 2016.

Kendati demikian, kewenangan PPAT untuk membuat akta otentik menyangkut perbuatan hukum tertentu mengenai Hak Atas Tanah dan Hak Milik Atas Satuan Rumah Susun masih menemui keragu-raguan. Hal ini terjadi sebagai akibat suatu akta otentik itu haruslah telah memenuhi unsur Pasal 1868 KUH-Perdata, yang berbunyi bahwa akta otentik ialah suatu akta yang dibuat dalam bentuk yang ditentukan undang-undang oleh atau dihadapan pejabat umum yang berwenang untuk itu ditempat akta itu dibuat. Melalui defenisi akta otentik dalam pasal tersebut, dapat diperoleh unsur-unsur pasal yang harus dipenuhi untuk dikatakan sebagai akta otentik itu berupa:

1. bentuk akta ditentukan oleh undang-undang;

2. akta dibuat oleh atau dihadapan pejabat umum;
3. Akta itu dibuat ditempat dimana akta itu dibuat.

Memperhatikan unsur-unsur dari Pasal 1868 KUHPerdata itu, dapat dipahami bahwa akta otentik yang dibuat oleh PPAT itu tidaklah memenuhi unsur pasal tersebut. Hal ini dipengaruhi oleh landasan hukum kewenangan pembuatan akta otentik oleh PPAT itu diatur dalam Peraturan Pemerintah, sementara untuk dikatakan sebagai akta otentik haruslah bentuk akta itu berada dibawah payung sebuah undang-undang.

Terlepas dari perdebatan mengenai akta PPAT sebagai akta otentik, umumnya akta PPAT itu juga diakui sebagai akta otentik. Diakuinya akta PPAT sebagai akta otentik telah mengakibatkan akta PPAT tersebut mempunyai nilai kekuatan pembuktian yang sempurna dan mengikat. Lilik Mulyadi menjelaskan bahwa pengertian "sempurna" itu dikarenakan akta tersebut cukup membuktikan tentang peristiwa atau hak. Konkretnya, sebagai bukti sempurna dalam arti bahwa ia tidak memerlukan penambahan alat bukti lagi. Sedangkan "mengikat" dimaksudkan bahwa apa yang ditulis dalam akta tersebut harus dipercaya hakim, yakni harus dianggap sebagai benar selama ketidakbenaran tersebut tidak dibuktikan sebaliknya. Dengan sebab demikian, PPAT sebagai pejabat umum merupakan seseorang yang diangkat dan diberhentikan oleh Pemerintah setelah memenuhi persyaratan tertentu yang ditetapkan oleh peraturan perundang-undangan untuk menduduki jabatan tertentu dan diberikan kewenangan memberikan pelayanan umum kepada masyarakat yang melakukan perbuatan hukum tertentu mengenai Hak Atas Tanah atau Hak Milik Atas Satuan Rumah Susun.

Kewenangan untuk membuat akta sebagai bukti telah dilakukannya perbuatan hukum tertentu mengenai Hak Atas Tanah atau Hak Milik Atas Satuan Rumah Susun itu adalah akan dijadikan dasar untuk pendaftaran perubahan data pendaftaran tanah yang diakibatkan oleh perbuatan hukum itu. Dalam hal ini, perbuatan hukum yang dimaksudkan itu adalah berhubungan dengan:

- jual beli;

- tukar menukar;

- hibah;

- pemasukan ke dalam perusahaan (inbreng);

- pembagian hak bersama;

- pemberian Hak Guna Bangunan/Hak Pakai atas Tanah Hak Milik;

- pemberian Hak Tanggungan; dan

- Pemberian Kuasa Membebankan Hak Tanggungan.

Dalam melaksanakan kewenangannya itu, Peraturan Pemerintah Nomor Nomor 24 Tahun 2016 telah menggolongkan pemangku jabatan PPAT ke dalam 3 (tiga) golongan, yakni:

1. PPAT sebagai pejabat umum, yakni pengangkatan PPAT dilaksanakan apabila telah memenuhi segala persyaratan yuridis-formal sebagaimana dimaksud dalam segala peraturan perudang-undangan yang berlaku. 
2. PPAT sebagai pejabat pemerintah, yakni pejabat yang memangku jabatan PPAT yang berlatar belakang dari pejabat pemerintah yang ditunjuk oleh Menteri dengan wilayah kerja meliputi wilayah kerjanya sebagai pejabat pemerintah yang menjadi dasar penunjukananya dan tentunya tanpa perlu memenuhi persyaratan formil sebagaimana dimaksudkan sebelumnya;

3. PPAT sebagai pejabat badan, yakni pejabat yang ditunjuk karena jabatannya untuk melaksanakan tugas PPAT dengan membuat akta PPAT tertentu khusus dalam rangka pelaksanaan program atau tugas pemerintah tertentu. Memperhatikan golongan dari PPAT tersebut, maka perlu dicermati lagi terkait dengan PPAT yang dijabat oleh pejabat pemerintah. PPAT jenis ini merupakan pejabat yang ditunjuk oleh karena jabatannya untuk melaksanakan tugas PPAT melalui pembuatan akta PPAT di daerah yang belum cukup terdapat PPAT.

Munculnya daerah- daerah yang belum cukup PPAT adalah dikarenakan oleh pemilihan wilayah kerja yang paling banyak dimohonkan, baik calon PPAT maupun perpindahan PPAT yang lama adalah di wilayah perkotaan, sedangkan untuk wilayah yang berada di pedesaan adalah sangat sedikit yang mengajukan permohonan penempatan kerja, sehingga menyebabkan di wilayah ini menjadi belum cukup terdapat PPAT. Dengan alasan itu, di daerah pedesaaan tersebut perlu diangkat PPAT Sementara (camat).

Pada awalnya, peralihan Hak Atas Tanah merupakan tugas dari Notaris, namun kewenangan itu dialihkan kepada PPAT sebagai wujud politik reformasi agraria yang tidak mengenal lagi dualisme kepemilikan Hak Atas Tanah, di mana dulunya Notaris hanya menginventarisasi peralihan kepemilikan hak barat saja. Namun, sebagai akibat tidak dikenal lagi penggolongan penduduk sebagaimana dikenal pada era Hindia-Belanda layaknya diatur dalam Indische Staatsregeling (IS), tentunya notaris wajib menyelenggarakan pelayanan hukum atas pembuatan akta otentik kepada seluruh masyarakat tanpa adanya diskriminasi ras, etnis, suku dan agama. Dengan sebab itu, seharusnya menyangkut peralihan Hak Atas Tanah itu dikembalikan lagi kepada Notaris. Alasannya, bidang peralihan Hak Atas Tanah itu juga merupakan bagian dari pekerjaan Notaris. Di samping itu, sekarang ini juga tidak dikenal lagi hak barat dan hak adat yang dapat membatasi gerak Notaris dalam membuat akta otentik. Jika hal ini diakomodasi, tentunya masalah legitimasi akta PPAT sebagai akta otentik akan dapat diatasi dan menyangkut segala persoalan legal validity of transaction dan authenticate contract dalam ranah hukum perdata akan berada pada satu pintu yang dikelola oleh lembaga Notaris.

Peraturan Menteri Agraria Nomor 10 Tahun 1961 juga menyebutkan bahwa yang dapat diangkat sebagai pejabat PPAT itu termasuk Notaris. Namun pada awal kemerdekaan, jabatan Notaris itu masih dijabat oleh para pejabat yang berasal dari zaman Pemerintahan
Belanda dan banyak Notaris yang berkewarganegaraan Belanda pulang kembali ke negara asalnya, sementara notaris- notaris yang ada di Indonesia pada waktu itu sangat sedikit, sehingga pemangku jabatan Notaris pun terjadi kekosongan pejabat yang memangku jabatan Notaris. Melalui alasan itu, diambillah kebijakan untuk menunjuk pejabat PPAT kepada pegawai-pegawai atau bekas pegawai di lingkungan Departemen Agraria dan pegawai-pegawai pamong praja. Dalam hal ini, tentunya Camat juga termasuk ke dalam pegawai-pegawai yang dimaksudkan itu.

Selanjutnya seiring dengan perkembangan hukum, konsep Camat sebagai PPAT, sekarang ini telah digeser politik hukumnya menjadi "di daerah yang belum cukup terdapat PPAT", di mana kontruksi pada awalnya menegaskan bahwa "untuk setiap Kecamatan atau daerah yang disamakan dengan itu, diangkat seorang penjabat pembuat akta tanah". Pergeseran itu dapat dibenarkan karena pada awalnya menganut prinsip setiap kecamatan itu ada satu PPAT (Camat) oleh karena terjadi kekurangan PPAT, kemudian beralih ke daerah- daerah atau tempattempat yang belum terdapat PPAT oleh karena terjadi kekosongan PPAT. Dengan kata lain, tidak ada lagi sentralisasi PPAT pada setiap kecamatan, namun hanya pada daerah pedalaman atau kecamatan terjauh saja yang ditempatkan PPAT Sementara. Namun harus disadari pula bahwa pengangkatan Camat sebagai PPAT Sementara tidaklah relevan lagi sebagai akibat dapat menimbulkan pertentangan norma. Sekarang ini, sudah jelas dikontruksikan bahwa PPAT itu merupakan pemangku jabatan umum sehingga PPAT dapat disebut sebagai pejabat umum dan tidak boleh merangkap jabatan sebagai pajabat pemerintah.

Camat sebagai PPAT Sementara adalah untuk memenuhi kebutuhan dalam reformasi agraria di Indonesia, kebutuhan akan tanah semakin meningkat, seiring dengan peningkatan pertumbuhan ekonomi. Penggunaan lahan pertanahan untuk kepentingan ekonomis, telah memacu pelayanan pendaftaran atas tanah yang dilakukan oleh Pemerintah kepada masyarakat semakin besar dimana dalam pendaftaran tanah tersebut diselenggarakan oleh Badan Pertanahan Nasional, yang dibantu oleh PPAT dan pejabat lain yang ditugaskan untuk melaksanakan kegiatan-kegiatan tertentu, mengenai pendaftaran tanah. Pejabat lain dalam hal ini dimaksud adalah Camat sebagai PPAT Sementara. Keterangan yang diperoleh pada Kantor Kecamatan Tamalate menegaskan bahwa:

"Kewenangan PPAT Kecamatan hanya melakukan Akta Jual Beli Hak Milik dari suatu perjanjian Pengikatan Jual Beli setelah pelunasan PPAT Kecamatan sama halnya tugas kewenangan jabatan dari Notaris yaitu membuat akta otentik Sedangkan PPAT Kecamatan sifatnya hanya sementara dan bekerja hanya di wilayah tersebut."

Hal ini berarti bahwa eksistensi Camat sebagai PPAT Sementara sangat terbatas karena batasan kewenangan yang dimiliki oleh camat sebagai PPAT sementara. Selain 
itu, kemajuan teknologi dan akses informasi yang semakin mudah didapatkan menyebabkan masyarakat semakin melek hukum dan memilih menggunakan jasa Notaris/PPAT untuk pendaftaran kepemilikan tanah.

Perlindungan Hukum Terhadap Para Pihak Yang Terikat dalam Perjanjian Pengikatan Jual Beli Hak Milik Atas Tanah di Kota Makassar.

Perjanjian Pengikatan untuk Jual Beli merupakan suatu perjanjian yang tidak diatur dalam Undang-Undang tetapi guna memberikan perlindungan hukum bagi para pihak dan menjaga kepentingan para pihak yang akan melakukan transaksi jual beli tanah atau tanah dan bangunan yang belum memenuhi syarat untuk dibuatkannya Akta Jual Beli maka berdasarkan Hukum Perjanjian dalam perkembangan yang dasarnya adalah Hukum Perjanjian yang baginya berlaku ketentuan hukum perikatan, dibuatkanlah Perjanjian pengikatan untuk Jual Beli. Mengenai hal itu diperkuat oleh ketentuan dalam KUHPerdata yang memberikan kebebasan bagi para pihak untuk membuat bahwa yang menentukan suatu perjanjian sepenuhnya menjadi kewenangan para pihak.

Perjanjian pengikatan untuk Jual Beli menganut sistem terbuka sebagaimana hukum perjanjian pada umumnya. Sistem terbuka dapat diartikan bahwa setiap orang dapat mengadakan perjanjian apa saja meskipun Undang-Undang tidak mengaturnya system terbuka ini beriring disebut sebagai "asas kebebasan berkontrak".

Meskipin suatu perjanjian berasaskan berkontrak tetapi didalam membuat suatu perjanjian tidak boleh bertentangan dengan Undang-Undang, kesusilaan dan ketertiban umum sisi positif dengan adanya asas kebebasan berkontrak ini adalah akan melahirkan perjanjian-perjanjian baik dimana perjanjian yang dimaksud tidak diatur dalam undang-undang tetapi sebenarnya dibutuhkan diantaranya ada lahirnya perjanjian Pengikatan untuk Jual Beli atas tanah atau tanah dan bangunan sebagai suatu solusi untuk menjaga kepentingan para pihak.

Jual beli yang dimaksud adalah didalam Pasal 26 Undang-undang Pokok Agraria Nomor 5 Tahun 1960 bahwa tujuan untuk memindahkan hak dalam jual beli tersebut haruslah memenuhi syarat-syarat yang ditentukan untuk itu. Sehingga nanti secara yuridis telah benar-benar terjadi adanya peralihan hak dengan pembuktian Akta Jual Beli serta sertifikat hak atas tanah yang telah dibalik nama ke atas nama pembeli.

Perjanjian pengikatan untuk Jual Beli dapat dikatakan adalah sebagai instrument yang dapat memberikan kekuatan hukum bagi para pihak yang akan melaksanakan suatu transaksi jual beli dengan syarat klausula yang terdapat dalam perjanjian untuk Jual Beli disetujui dan disepakati oleh para pihak dan apa yang dianggap sebagai klausula dari Perjanjian untuk Jual Beli tidak bertentangan dengan Undang-undang, kesusilaan dan ketertiban umum serta ditandatangani oleh para pihak dihadapan Pejabat yang berwenang untuk itu yaitu seorang Notaris sehingga kemudian perjanjian itu akan disahkan oleh Notaris sebagai Akta Otentik.

Kepercayaan juga merupakan salah satu kunci dibuatkannya Perjanjian pengikatan untuk Jual beli karena apabila tidak ada rasa saling percaya diantara para pihak maka perjanjian yang diinginkan itu tidak akan pernah terealisasi. Misalnya dalam hal kedudukan seseorang dalam transaksi jual beli adalah sebagai penjual, ia tidak mau menyerahkan sertifikat ha katas tanahnya kepada pembeli melalui kantor Notaris karena adanya rasa tidak percaya akan itikad baik dari pembeli sedangkan untuk dibuatnya Perjanjian Pengikatan untuk jual beli diisyaratkan sertifikat hak atas tanah harus dicek terlebih dahulu ke Kantor Pertaanahan sehingga adanya hal tersebut pembuatan perjanjian akan menjadi terhambat.

Pihak pembeli adanya rasa tidak percaya ini dalam hal pembayaran atas transakasi jual beli tanah atau tanah dan bangunan dimana calon pembeli tidak mau menyerhkan sebagaian uang atau keseluruhan uang yang menjadi nilai dari objek jual beli dikarenakan masih ada kekhawatiran tentang keabsahan sertifikat ha katas tanah yang bersangkutan sehingga dalam hal ini transaksi jual beli yang direncanakan akan terancam batal jadi kepercayaan juga merupakan hal yang utama didalam pembuatan suatu perjanjian.

Perjanjian pengikatan untuk Jual beli yang dibuat dihadapkan seorang Notaris merupakan akta tambahan yang dibuatkan dalam hal adanya peristiwa-peristiwa khusus yang mengakibatkan tidak dimungkinkan untuk transaksi jual beli yang dilakukan dengan dibuatkannya Akta Jual Beli tetapi dengan alasan perjanjian itu dibuat secara sah oleh para pihak maka perjanjian itu akan berlaku sebagai undang-undang bagi mereka yang membuatnya dan dibuat secara sah berdasarkan Pasal 1338 ayat (1) Kitab Undang-undang Hukum Perdata dan akan mengikat para pihak sampai terpenuhinya prestasi yang menjadi hak dan kewajiban masing-masing pihak tersebut.

Perjanjian pengikatan untuk Jual Beli ini belum memindahkan hak melainkan hanya merupakan suatu hubungan timbal balik yang memberikan hak dan kewajiban bagi masing-masing pihak dalam pemenuhan suatu prestasi. Perjanjian pengikatan untuk jual beli ini hanya merupakan suatu perjanjian Antara para pihak yang membuatnya sehingga hak dan kewajiban yang dibebankan kepada masing-masing pihak akan dapat dijalankan sebagaimana mestinya karena didalam perjanjian Pengikatan untuk Jual Beli diatur mengenai sanksi-sanksi yang dapat diterima para pihak apabila pelaksanaan hak dan kewajiban tersebut tidak dilakukan sebagaimana mestinya.

Perlindungan hukum lainnya yang dapat diberikan oleh perjanjian Pengikatan untuk Jual Beli sehubungan dengan perbuatan hukum peralihan ha katas tanah adalah apabila dilihat dari syarat sahnya perjanjian yang terdapat didalam Pasal 1320 Kitab Undang-Undang Hukum Perdata bahwa Perjanjian Pengikatan untuk Jual Beli tidak dapat terlepas dari syarat sahnya penjanjian itu dan 
dapat dikatakan sebagai salah satu intrumen hukum yang dapat memberikan perlindungan bagi para pihak yang bertransaksi dan membuat perjanjian.

Sebagai suatu perjanjian berdasarkan kesepakatan, perjanjian pengikatan untuk Jual Beli akan memberikan perlindungan hukum yang sama besarnya Antara pihak penjual sebagai pemilik tanah atau tanah dan bangunan serta pihak pembeli selaku pemilik uang yang akan membayar harga atas transaksi jual beli yang akan dilakukan.

Berbeda dengan perjanjian yang dibuat secara baku, Karena perjanjian baku ini sering mengakibatkan perlindungan hukum yang tidak seimbang Antara para pihak dan biasanya perlindungan Hukum yang diterima oleh pihak yang membuat perjanjian yaitu kreditu akan lebih besar dibandingkan dengan perlindungan hukum yang akan diterima oleh seorang debitur.

PPJB dibuat untuk digunakan sebagai bukti yang kuat jika suatu saat terjadi perselisihan antara para pihak lain dimana Akta adalah tulisan yang dibuat secara khusus yang dibuat sedemikian rupa agar menjadi suatu alat bukti yang sah dan akurat. Dimana peran Notaris dalam membantu masyarakat umumnya untuk membuat akta yang memiliki kekuatan hukum.

1. Tanggapan Responden Mengenai Wewenang Notaris

dan PPAT dalam Pembuatan Akta Perjanjian

Pengikatan Jual Beli Hak Milik Atas Tanah Di Kota

Makassar.

Penelitian yang dilakukan penulis dilaksanakan dengan membagikan beberapa angket kepada masyarakat sebanyak 50 orang kepada masyarakat secara rinci dapat dilihat pada table dibawah ini:

Table 1. Pendapat Responden Mengenai Wewenang Notaris dan PPAT

\begin{tabular}{lll}
\hline Tanggapan Responden & Frekuensi & Presentase \\
\hline Ya & 15 & $38 \%$ \\
Tidak & 35 & $62 \%$ \\
\hline Jumlah & 50 & $100 \%$ \\
\hline
\end{tabular}

Berdasarkan uraian data diatas dapat diketahui bahwa dari 50 orang Responden, $62 \%$ diantaranya tidak mengetahui apa kewenangan notaris dan PPAT. Hal ini disebabkan karena minimnya pengetahuan hukum masyarakat. Anggapan umum yang ada dimasyarakat adalah bahwa Notaris dan PPAT adalah profesi yang berhubungan dengan melegalkan perjanjian dan membantu pengurusan hal-hal yang berkaitan dengan pertanahan. Meski Notaris dan PPAT memiliki kewenangan yang berbeda, namun PPAT adalah profesi yang boleh dirangkap oleh Notaris. Dari 50 orang respon, $38 \%$ diantaranya yakni sebanyak 15 orang telah mengetahui kewenangan Notaris dan PPAT sesuai dengan Undang-Undang-Undang Jabatan Notaris dan Peraturan Pemerintah tentang PPAT.

2. Tanggapan Responden Mengenai Perbedaan Notaris PPAT dan PPATS Di Kecamatan Dalam Pembuatan Akta Perjanjian Pengikatan Jual Beli Hak Milik Atas Tanah Di Kota Makassar.
PPATS (sementara) adalah Pejabat Pemerintah yang ditunjuk karena jabatannya untuk melaksanakan tugas PPAT dengan membuat Akta PPAT di daerah yang belum cukup terdapat PPAT. Hasil wawancara H.Sikki,SH selaku Staf PPAT dikantor Kecamatan Tamalate menyatakan bahwa;

"Kewenangan PPAT Kecamata hanya melakukan Akta Jual Beli Hak Milik dari suatu perjanjian Pengitan Jual Beli setelah pelunasan PPAT Kecamatan sama halnya tugas kewenangan jabatan dari Notaris yaitu membuat akta otentik Sedangkan PPAT Kecamatan sifatnya hanya sementara dan bekerja hanya di wilayah tersebut".

Hasil penelitian melalui pengisian kuisioner tergambar dalam tabel dibawah yang memuat tentang pendapat responden mengenai pengetahuan masyarakat tentang tugas pokok dan fungsi antara Notaris, PPAT, dan PPATS yakni sebagai berikut:

Table 2. Pendapat Responden Mengenai Perbedaan Notaris, PPAT, dan PPATS

\begin{tabular}{lll}
\hline Tanggapan Responden & Frekuensi & Presentase \\
\hline Ya & 24 & $48 \%$ \\
Tidak & 26 & $52 \%$ \\
\hline Jumlah & 50 & $100 \%$ \\
\hline
\end{tabular}

Berdasarkan uraian data diatas dapat diketahui bahwa jumlah responden yang mengisi kuisioner sebanyak 50 responden. Data menunjukan bahwa masyarakat yang mengetahui tentang perbedaan Notaris dan PPAT adalah sebanyak 24 dengan presentase sebesar $48 \%$. Sedangkan yang menjawab tidak mengetahui sebanyak 26 orang dengan presentase sebesar 52\%. Ini menunjukan bahwa tingkat pemahaman masyarakat mengenai perbedaan antara Notaris, PPAT, dan PPATS masih rendah. Hal ini disebabkan karena keterbatasan akses informasi yang diperoleh masyarakat. Sebagian masyarakat hanya melihat secara visual seperti Plang Nama Notarsi dan PPAT dalam satu plang yang sama sehingga mereka berasumsi bahwa kedua profesi ini memiliki tugas dan kewenangan yang sama.

Masyarakat seharusnya memahami perbedaan Notaris, PPAT, dan PPATS karena tugas pokok dan fungsinya berbeda dalam hukum administrasi. Notaris merupakan pejabat umum yang berwenang untuk membuat akta otentik dan kewenangan lainnya sebagaimana dimaksud dalam Undang-Undang N0.2 Tahun 2014 (Pasal 1 angka 1 UUJN) sedangkan PPAT adalah pejabat umum yang diberi kewenangan untuk membuat akta-akta otentik mengenai perbuatan hukum tertentu mengenai hak atas tanah atau Hak Milik Atas Satuan Rumah Susun (Pasal 1 angka 1 PP 37/1998). Selain itu, sistem pembinaan dan pengawasannya juga berbeda sesuai dengan ketentuan yang berlaku.

\section{KESIMPULAN DAN SARAN}

Berdasarkan uraian pembahasan dan hasil di atas, maka dapat ditarik kesimpulan sesuai 1. Wewenang Notaris dalam Pembuatan Akta Perjanjian Pengikatan Jual 
Beli Tanah yang ada di Kota Makassar merupakan kewenangan yang melekat pada Notaris untuk membuat akta mengenai semua perbuatan, perjanjian dan penetapan yang diharuskan oleh peraturan Perundangundangan dan/atau yang dikehendaki oleh yang berkepentingan untuk dinyatakan dalam Akta Autentik termasuk perjanjian pengikatan jual beli, dengan ketentuan bahwa semua persyaratan dalam pembuatan akta terpenuhi dengan lengkap baik berdasarkan peraturan perundang-undangan yang berlaku.

Perjanjian Pengikatan Jual Beli dapat digunakan sebagai salah satu bentuk perlindungan hukum bagi para pihak yang termuat dalam perjanjian tersebut dan dapat menjadi salah satu alat bukti jika suatu saat terjadi perselisihan antara para pihak karena akta Perjanjian Pengikatan Jual Beli diakui sebagai alat bukti yang sah dan akurat bagi para pihak yang melakukan transaksi perjanjian jual beli sebagaimana disebutkan dalam Undang-Undang bahwa akta autentik digunakan sebagai alat bukti dengan pembuktian sempurna dihadapan hukum.

\section{DAFTAR PUSTAKA}

Fernando M Manulang, Hukum Dalam Kepastian, Prakarsa, Bandung, 2007, hal. 95.

Guasman Tatawu, Hakekat Hukum Putusan Mahkamah Konstitusi Terhadap Sengketa Pemilihan Kepala Daerah (Pilkada), Holrev. Volume 1 Issue 2, September 2017. hal.144-165. http://ojs.uho.ac.id/index.php/holrev/article/view/36 39 (diakses tanggal 25 Januari 2021).

Gunawan widjaja dan Kartini Muljadi, 2003, Jual Beli : Grafindo Persada, Jakarta. hal. 3.

Habib Adjie, 2009, Sanksi Perdata dan Administratif Notaris Sebagai Pejabat Publik, PT.Refika Aditma, Jakarta. hal. 85 .

Herlien Budiono, artikel "Pengikat Jual Beli Dan Kuasa Mutlak" Majalah Renvoi, edisi tahun I, No 10, Bulan Maret 2004, hal. 57.

Ilham, Z., Pananrangi, A. R., \& Bahri, S. (2020). Pengaruh Kepemimpinan Dan Lingkungan Kerja Terhadap Semangat Kerja Asn Di Sekretariat Daerah Kabupaten Majene. Jurnal Paradigma Administrasi Negara, 3(1), 7-11.

Jimly Asshiddiqie, Konstitusi dan Konstitusionalisme Indonesia, Cetakan ke-4, Sinar Grafika, Jakarta, 2017, h. 128.

Lili Rasjidi dan B.Arief Sidharta, Filsafat Hukum Madzab dan Refleksi (Bandung: PT. Remaja Rosda Karya,1994),64.

Muh. Hasrul, 2013, Eksistensi Gubernur Sebagai Wakil Pemerintah Pusat di Daerah Dalam Mewujudkan Pemerintahan yang Efektif, Disertasi, Program Doktor Fakultas Hukum Universitas Hasanuddin, Makasar, hal.15.
Muh. Jufri Dewa, 2011, Hukum Administrasi Negara dalam Perspektif Pelayanan Publik, Unhalu Press, Kendari, hal. 114.

Pasal 1 angka 1 Undang-Undang Nomoe 2 Tahun 2014 Tentang Perubahan Undang-Undang Nomor 30 Tahun 2004 tentang Jabatan Notaris.

Peter Mahmud Marzuki, Pengantar Ilmu Hukum, Kencana, Jakarta, 2008, hal. 158.

Philipus M. Hadjon, 1987, Perlindungan Rakyat Bagi Rakyat di Indonesia(sebuah Studi tentang PrinsipPrinsipnya, Penanganannya oleh Pengadilan dalam Lingkungan Peradilan Umum.

R. subekti, 1995, Aneka Perjanjian, Penerbit : PT. Citra Aditya Bakti, Bandung. hal 1.

Riduan Syahrani, Rangkuman Intisari Ilmu Hukum, Citra Aditya Bakti, Bandung, 1999, hal. 23.

Satjipto Rahardjo, Hukum Dalam Jagat Ketertiban, UKI Press, Jakarta, 2006, h. 135-136.

Satjipto Rahardjo,Ilmu Hukum (Bandung: Citra Aditya Bakti, 2000), hal. 53.

Setiono, Rule of Law (Supremasi Hukum), 2004, Tesis Magister Ilmu Hukum Program Pascasarjana Universitas Sebelas Maret,Surakarta, hal.3.

Siti Hasnati, wawancara Notaris dan PPAT, hari selasa tanggal 10 November 2020 jam 13.00 Wita

Sudikno Mertokusumo dalam Salim HS, Perkembangan Teori Dalam Ilmu Hukum, Raja Grafindo Persada, Jakarta, 2010, hal. 82.

Sudikno Mertokusumo, Mengenal Hukum Suatu Pengantar, Liberty, Yogyakarta, 2007, hal. 160.

Suhartono, 2010. Perjanjian, Asas Proforsional, Kompas, Jakarta, hal 233.

Suhrawardi, 2000.Hukum Waris Islam Edisi 2. Sinar Grafika, Yogyakartahal 128.

Urip Santoso, Pejabat Pembuat Akta Tanah; Perspektif Regulasi, Wewenang dan Sifat Akta, Jakarta: Kencana, 2016, hal. 62-63

Wawancara dengan H.Sikki, SH sebagai Staf PPAT dikantor Kecamatan Tamalate hari selasa tanggal 11 November 2020 jam 13.00 Wita.

Zainal Asikin, Pengantar Tata Hukum Indonesia, Rajawali Press, Jakarta, 2012, h.65. 